\title{
SMALL-SLBUNIT RIBOSOMIAL RNA GENE IDENTIFICATION OF THE HUMAN PATHOGEN SCHISTOSOMA SP. IN EGYPT
}

\author{
Mohammed H. Awwad and Gazaa H. Morsy \\ Department of Zoology, Faculty of Science, Zagazign Lniversity. \\ Benha Branch
}

Key words: Identification. Schistosoma, nsrDNA. rRNA gene.

\begin{abstract}
The polymerase chain reaction and restriction fragment length 1 polymorphism (RFLP) of the $18 \mathrm{~S}$ rRNA gene, utilizing the enzyme BspMI, were used for the molecular identification of the two species of Schistosoma (haematobium and mansoni). The RFLP profiles extracted using this enzyme were highly characteristic of the two species and exhibited low levels of intraspecific polymorphism among samples from different regions of Egypt. However, $S$. haematobium and $S$. mansoni showed very similar profiles that complicated their identification at the molecular level and promised a very close genetic similarity between the two species. Other enzymes including Accl, AvaII and SnaBI were tested for their ability to differentiate between these species. The study pointed out that the $18 \mathrm{~S}$ rRNA gene contains effeclive genetic markers for the identification of these Schistosoma spp..
\end{abstract}

\section{INTRODUCTION}

In areas where schistosomiasis is endemic, infections are heterogeneous; low and high levels of infection may be recorded in peoples living in similar conditions of exposure to the parasite. Schistosomiasis is a major public health problem, which has afflicted more than 300 million people throughout 76 countries, especially in the tropics (Iida et al.,1999). Human schistosomiasis is a permanent and continues to be one of the most common parasitic infections in tropical and subtropical environments (WHO, 1999). Owing to its chronic nature, the disease impacts labor capacity, thus having a major negative impact on the socio-economic development of endemic regions (Tanrer, 1989). Schistosomiasis is directly related to 
water sources; in view of the large number of water resource schemes being developed, it is expected that the disease will gain more recognition (Mott et al., 1995). Schistosomiasis remains the most prevalent parasitic disease causing a major public health problem in Egypt. Both Schistosoma mansoni and S. haematobium are found in Egypt (WHO 1999). Egypt currently has the highest frequency of bladder cancer in the world, due to urinary schistosomiasis(Savioli et al., 1990; WHO 1994; and El-Rifai et al., 2000). S. mansoni and S. haemalobium have been more commonly identified in cases of spinal cord lesions (Haribhai et al., 1991; Selwa et al., 1991; Ueki et al., 1995; Scully et al., 1996; Iida et al., 1999 and Leite et al., 2000), with the infections characterized by mass lesions resulting from a dramatic host inflammatory response to ova deposited in the brain (Scrimgeour \& Gajdusek, 1985 and Pitella 1991; 1997). Schistosoma mansoni is a chronic infection which leads to intestinal schistosomiasis, liver fibrosis, cirrhosis, hepatosplenic schistosomiasis and hepatocellular carcinoma in a large percentage of untreated individuals (WHO, 1993; McCully ef al., 1996 and lida et al., 1999).

The morphological identification of freshwater Schistosoma mansoni and $S$. haematobium is of great medical importance. The process, however, is complicated by the extensive intraspecific variation of the morphological characteristics used for classical identification. A previous study has proven it possible to distinguish different geographical isolates by allozyme electrophoresis (Chilton et al., 1997).In another approach, Johansen et al.(1997) were successful in the in-vivo radiolabelling of cercariae of Schistosoma. To solve this problem, the use of molecular techniques as additional tools for the identification of these organisms has been suggested. It involves using the $18 \mathrm{~S} \mathrm{rDNA}$ of such organisms by means of $\mathrm{PCR}$ amplification and digestion with different restriction enzymes. This method was successfully employed to construct the molecular key for Aedes species West et al., (1997). It was also used to distinguish closely related parasitic worms and other different organisms (Wu et al., 1999) and. instudies of genetic variation and identification of snails of the genera Oncomelania, Bulinus and Biomphalaria (Hope \& McManus 1994; Stothard et al., 1996; Stothard \& Rollinson, 1997; Caldeira et al., 1998; Rollinson et al., 1998; Vidigal et al., 1998a,b and Spatz et al., 1998; 1999).

The aim of the present study was to investigate the use of restriction profiles resulting from digestion of the $18 \mathrm{~S}$ rDNA of $S$. mansoni and $S$. haematobium including some restriction enzymes 
such as BspMI, Accl. AvaII and SnaBI for identification of these species.

\section{MATERIAL AND METHODS}

Biological Materials - Cercariae of $S$. mansoni and $S$. haematobium were collected in $750 \mathrm{mi}$ of distilled water from infected Biomphalaria sp. and Bulinus sp. snails attained from fresh water streams in four different provinces in Egypt (El-Qualyobia. ElSharkaia, El-Dakahlia and Asuit), using light induction method (Lim et al., 1999). Cercariae were shed from Biomphalaria sp. and Bulinus sp. snails in water and collected by sedimentation for about 20 minutes on ice.

DNA extraction - The current molecular biology study was carried out in Faculty of Science-Zagazig University-Benha branch. Total DNA was extracted from the cercariae of $S$. mansoni and $S$. haematobium using the Wizard Genomic DNA Purification Kit (Promega) with some modifications. Briefly, the tissues were mechanically dispersed in $200 \mu \mathrm{l}$ of nucleic lysis solution and incubated at $37^{\circ} \mathrm{C}$ for $4 \mathrm{~h}$ or overnight with $50 \mu \mathrm{g} / \mathrm{ml}$ proteinase $\mathrm{K}$. Thereafter, $80 \mu \mathrm{l}$ of protein precipitation solution was added to the initial mix. The mixture was vortex vigorously for $10-20 \mathrm{sec}$ and centrifuged at $13,000 \mathrm{rpm}$ for $5 \mathrm{~min}$. The supernatant was transferred to a microcentrifuge tube containing $200 \mu \mathrm{l}$ of ronm temperature isopropanol for DNA precipitation. The mixture was gently mixed by inversion for $20 \mathrm{~min}$ and centrifuged at $13,000 \mathrm{rpm}$ for $5 \mathrm{~min}$. The DNA pellet was washed with $300 \mu l$ of $70 \%$ ethanol and centrifugrd for $1 \mathrm{~min}$. The pellet was treated with $25 \mu$ of DNA rehydration solution for $30 \mathrm{~min}$ at $65^{\circ} \mathrm{C}$ and stored at $-20^{\circ} \mathrm{C}$. The DNA concentrations were estimated by comparison with known standards on $2 \%$ ethidium bromide stained agarose gels.

Amplification by PCR-The entire nuclear srDNAwas amplified, using the primers SSU1 (5'-CGACTGGTTGATCCTGCCAGTAG-3') and SSU2 (3'-TCCTGATCCTTCTCAGGTTCAC-5") (Amresco)anchored respectively in the conserved extremities of the $18 \mathrm{~S}$ ribosomal genc (Stothard \& Rollinson, 1997). The PCR amplification was undertaken in a volume of $10 . \mu \mathrm{l}$ consisting of: 1-10 ng template DNA, $10 \mathrm{mM}$ Tris-HCl, pH8.5,200 $\mu \mathrm{m}$ each dNTP, $1.5 \mathrm{mM} \mathrm{MgCl} \mathrm{2,0.8} \mathrm{U} \mathrm{of} \mathrm{Taq}$ DNA polymerase, $50 \mathrm{mM} \mathrm{KCl}$, together with 5.0 pmol of each primer. The reactions were covered with a drop of mineral oil and subjected 
to the following cycle program: initial denaturation step for $3 \mathrm{~min}$ at $95^{\circ} \mathrm{C}$, and then 32 cycles with annealling at $54^{\circ} \mathrm{C}$ for $1 \mathrm{~min}$, extension at $72^{\circ} \mathrm{C}$ for $2 \mathrm{~min}$, denaturation at $95^{\circ} \mathrm{C}$ for $45 \mathrm{sec}$ and a final extension step at $72^{\circ} \mathrm{C}$ for $5 \mathrm{~min}$. A negative control (no template DNA) was included in all phases of the experiment. Three microlitres of the amplification products were visualized on $0.8 \%$ ethidium bromide stained agarose gels to check the quality of amplification. The remaining $7 \mu \mathrm{l}$ were mixed with $53 \mu \mathrm{l}$ of water, and divided into $10 \mathrm{Hl}$ aliquots for enzyme digestion.

Production and Evaluation of the Nuclear rDNA-18S RFLP Profiles-In the initial experiments, the enzyme BspMI (Amersham, Life Science) was evaluated for its ability to differentiate all Schistosoma species within Egypt. Additional enzymes were tested including Accl, Avall, (Boehringer Mannheim) SnaBI (Sigma Co, USA) in cases when BspMI was not effective in the separation of the two species. One microlitre (10-12 units) was used for each digestion reaction, together with $1.2 \mu \mathrm{l}$ of the respective enzyme buffer for a final volume of $12.2 \mu \mathrm{l}$. The digestion was performed for $3.5 \mathrm{~h}$ at $37^{\circ} \mathrm{C}$, and the digestion products were evaluated on $2 \%$ TBE-agarose (FMC .Bioproducts) gels and stained with ethedium bromide. Bands were detected upon ultraviolet transillumination and photographed (35mm Kodak Film, England).

\section{RESULTS}

DNA genome was extracted from $S$. mansoni and $S$. haematobium and collected from the four provinces and represented in Figure 1. This shows DNA genome from $S$. mansoni and $S$. haematobium isolates, lanes 1 - 4 represent $S$. mansoni DNA genome which were isolated from El-Qualyobia, El-Sharkaia, El-Dakahlia and Asuit provinces, respectively and lanes 6-9 represent $S$. haematobium DNA genome which . were isolated all from the same provinces. The full-length nuclear small subunit ribosomal RNA (srRNA) gene PCR products from $S$. mansoni and $S$. haematobizm with primers SSU1 and SSU2 resulted in a product of approximately $\sim 2 \mathrm{~kb}$ (Fig. 2). Figure 2 symbolized full-segment srDNA of Schistosoma sp. isolates, lanes 1 - 4 represented srDNA of $S$. mansoni from El-Qualyobia, ElSharkaia, El-Dakahlia and Asuit provinces, respectively, lanes $5-8$ represented srDNA of $S$. haematobium from the same provinces. Schistosoma sp. isolates, which were collected from all provinces, give the same results when their nuclear rDNA was digested with the 
different restriction endonucleases. All isolates were digested with BspMI. Figure 3 shows the representative RFLPs patterns from $S$, mansoni and $S$. haematobium from each isolate (province) with BspMI, which produced roughly the same fragments ( 2 bands, $\sim 500$ and $-1500 \mathrm{bp}$, for all isolates). This enzyme produced a simple profile with two fragments, which were clearly similar for all isolates. Accl restriction enzyme digested the nsrDNA of $S$. mansoni into 3 different band sizes $(-450, \sim 500$, and $\sim 950$ bp,lanes 1-) rom II provinces's isolates, (Fig. 4). The same restriction enzyme cut the nsrDNA of $S$. haematobium to 2 bands $(-500$ and $\sim 1500 \mathrm{bp}$, lanes 5 8) from all provinces's isolates, (Fig. 4).In analysis of the nuclear srRNA gene, Avall enzyme resulted in two RFLPs with $S$. mansoni $(\sim 800$ and $-1200 \mathrm{bp}$, lanes $1-4)$, but digested nsrDNA of $S$. haematobium into three patterns $(\sim 500, \sim 600$ and $\sim 900)$, figure 5 . The nuclear gene of Schistosoma sp. isolates was identified by one restriction enzyme. The nuclear gene of $S$. mansoni was digested uniquely by SnaBI ( $\sim 500$ and $\sim 1500$ bp, lanes1- 4), whereas S. haematobium nuclear gene was not digested at all by this restriction enzyme,( Fig. 6 lanes5 - 8).

\section{DISCUSSION}

In this research, it has been attempted to determine whether the two isolates of $S$. mansoni and $S$. haematobium, from ElQualyobia, El-Sharkaia, El-Dakahlia and Asuit provinces (with any mutational differences among the isolates), that have been identified, belong together to a single species, or they are isolates distantly related. The problem is important because $S$. mansoni and $S$. haematobium are human pathogens and there were many difficulties with classification of pathogenic Schistosoma strains or isolates in the past. There was an indication in the past, however, that it might be monophyletic, but there was a need for more definitive test of this possibility. Our approach to this problem was to use a modern method of studying relationships among $S$. mansoni and $S$. haemalobium isolates in which phylogeny is reconstructed on the basis of nuclear srDNA RFLPs. Differences in electrophoretic patterns are known as RFLPs (Restriction Fragment Length Polymorphisms). The contribution was to find the sites in the nuclear srRNA genes where different endonucleases enter. Pires et al.(1997), Caldeira et al. (1998), Vidigal et al.(1998), Spatz et al.(1999) Wu et al.(1999)and 
Vidigal et al. (2000) used restriction fragment length polymorphisms (RFLPs) of Schistosomal snails DNA as a basis for examining relationships among strains. The possibility of using restriction enzyme analysis of the nuclear srRNA genes as an experimental tool to identify the two strains proved valid (S.mansoni and Shaemalobium) and to find specific enzymes to identify individual strains.

BspMI restriction enzyme did not differentiate nsrDNA of $S$. mansoni and $S$. haematobium isolates that digested the genes into approximately two similar band lengths of all isolates (Fig. 3). This indicated that $S$. monsoni and $S$. haemalobium isolates may be of the same species, or monophyletic. There are two restriction enzymes (AccI and AvalI) that differentiated nsrDNA of $S$. mansoni and $S$. haematobium of all isolates.AccI restriction enzyme it digested nsrDNA of $S$. mansoni to three RFLPs profile $(-450, \sim 500$, and $\sim 950$ $\mathrm{bp})$, whereas it digested $S$. haematobium to two fragments $(\sim 500$ and $\sim 1500$ bp),(Fig. 4). Avall restriction enzyme cut nsrRNA genes of $S$. mansoni to two restriction patterns $(-800$ and 1200$)$, but digested that of S.haematobium into three bands $(-500, \sim 600$, and $\sim 900 \mathrm{bp}$ ), (Fig. 5).Thus, AccI and AvalI restriction enzymes are the best restriction enzymes for differentiation of $S$. mansoni and $S$. haematobium. This indicates that $S$. mansoni and $S$. haematobium isolates might be different species. It has been found that we can identify $S$. mansoni isolate by RFLPs obtained by using specific endonuclease to digest nsrDNA PCR product. There is one restriction enzyme, SnaBI, that gave unique RFLPs for $S$. mansoni through digestion of nsrDNA and gave a negative result with $S$. haematobium (Fig. 6).

So, PCR-RFLP is a simple and rapid technique representing an important advance for studies of Egyptian Schistosoma species, which can be used as a complementary tool to morphological identification. The study demonstrated that nsrDNA (nsrRNA genes) contain useful genetic markers for the identification of these Schistosoma (mansoni and haemalobium). The present data proved that $S$. mansoni, which was collected from four provinces of Egypt, have similar strains and so are $S$. haematobium. The results obtained with PCR-RFLP accord with the actual morphological systematics proposed for the Egyptian Schistosoma. 


\section{REFERENCES}

Caldeira, R. I.;Vidigal. T. H.; Paulinelli, S. T.; Simpson, A. J.and Carvalho O. S. (1998). Molecular identification of similar species of the genus Biomphalaria (Mollusca: Planorbidae) determined by a PCR-RFLP. Memórias do Instituto Oswaldo Cruz.,93: 219-225.

Chilton, N.B.; Beveridge, I. and Andrews, R.H. (1997). An electrophoretic analysis of patterns of speciation in Cloacine clarkae, $C$. communis, $C$. petrogale, and $C$. similis Nematoda: Strongyloidea) from macropodial marsupials. International J. Parasitol.,27: 483-493.

El-Rifai, W, D.; Larramendy, M. L.; Shoman, S.; Gad Y.; Baithun S;El-Awady, M.; Eissa S.; Khaled. H.; Soloneski S.; Sheaff $M$. and Knuutila S.(2000). DNA copy number changes in Schistosoma-Associated and Non-Schistosoma-Associated bladder cancer. Ameri. J. Pathol.,156(3): 871-878.

Haribhai, H. C.; Bhigjee A. I. And Bill P. L., (1991). Spinal cord schistosomiasis. Brain., 114: 709-726.

Hope, M. and McManus D.P.(1994).Genetic variations in geographically isolated populations and subspecies of Oncomelania hupensis determined by a PCR-based RFLP method Acta Tropica., 57:75-82.

Iida, F.; Iida, R.; Kamijo H., Takaso, K., Miyazaki, Y.; Funabashi,W.; Tsuchiya, K. and Matsumoto Y.(1999).Chronic Japanese schistosomiasis and hepatocellular carcinoma: ten years of follow-up in Yamanashi Prefecture, Japan 581 Bulletin of the World Health Organization., 77 (7): 573-581.

Johansen, M. V.; Christensen, Né. and Nansen, P.(1997).In vivo labeling of Schistosoma japonicum Cercariae with 35S. J. Parasitol., 83: 5-6. 
Leite, C.C.: Souza, A.F.: Valente, M.; Araujo, M. A. and Jinkins J. R. (2000). Clinics in Diagnostic Imaging (52) Singapore Medical J. ,4I(8) : 417-419

McCully, R.; Barron, C. and Cheever, A. (1996). Schistosomiasis. In: Binford C,Connor D,eds.Patholegy of Tropical and Extraordinary Diseases. Washington, DC: Armed Forces Institute of Pathol., 1976: 482-508.

Mott, KE.; Nuttall, I.; Desjeux, P. and Cattand, P. (1995). New geographical approaches to control of some parasitic zoonoses. Bulletin of the World Health Organization. ,73: 247-257.

Pires, E. R.;Vidigal, T.H.A.; Teles, H.M.;Simpson,A. J. and Carvalho O.S. (1997). Specific identification of Biomphalaria tenagophila and Biomphalaria occidentalis populations by the Low Stringency Polymerase Chain Reaction. Memórias do Instituto Oswaldo Cruz ,92: 101-106.

Pitella, J. E. (1991). The relation between involvement of the central nervous system in Schistosomiasis mansoni and the clinical forms of the parasitosis. A review. Amer. J. Trop. Med. Hyg., 94: 15-21.

Rollinson, D.; Stothard, J. R.; Jones, C. S.; Lockyer, A. N.; Souza, C. P. and Noble L. R. (1998). Molecular characterisation of intermediate snail host and the search for resistance genes.Memórias do Instituto Oswaldo Cruz.,93: 111-116.

Savioli, L.; Hatz, C.; Dixon, H.; Kisumku, U. M. and Mott, K. E. (1990). Control of morbidity due to Schistosoma haematobium on Pemba Island: egg excretion and haematuria as indicators of infection. The Amer. J. Trop. Med. Hyg., 43 (3): 289-295.

Scrimgeour, E. M. and Gaidusek, D.C. (1985). Involvement of the central nervous system in Schistosoma mansoni and $S$. haematobium infection: A review. Brain., 8: 1023-1038. 
Scully, R. E.; Mark, E. J.: McNeely, W. F. and Eberling. S. H. (1996). Weekly clinicopathological exercises. The New England J. Med., 334: 382-389.

Selwa, L. M.; Brunberg, J. A.; Mandell, S. H. and Garofalo, EA. (1991). Spinal cord schistosomiasis: a pediatric case mimicking intrinsic cord neoplasm. Neurol., 1 1: 755-757.

Spatz, L.; Vidigal, T. H. A.; Caldeira, R. L.; Dias N. E.; Cappa S. M. and Carvalho, O.S.(1998). Molecular study of similar Biomphalaria species. Memórias do Instituto Oswaldo Cruz.,93: 169-170.

Spatz, L.; Vidigal, T. H. D. A.; Caldeira, R. L.; Dias Neto, E.; Cappa, S. M. G. and Carvalho OS. (1999). Study of Biomphalaria tenagophila, $B$. t. guaibensis and $B$. occidentalis by polymerase chain reaction amplification and restriction enzyme digestion of the ribosomal RNA intergenic spacer regions. J. of Moll. Stud., 65: 143-149.

Stothard, J. R.; Hughes, S. and Rollinson, D. (1996). Variation within the internal transcribed spacer (ITS) of ribosomal DNA genes of intermediate snail hosts within the genus Bulinus (Gastropoda: Planorbidae). Acta Tropica, 61: 19-29.

Stothard, J. R. and Rollinson, D. (1997). Molecular characterization of Bulinus globosus and B.nasutus in Zanzibar, and an investigation of their roles in the epidemiology of Schistosoma haematobium. Transactions of the Royal Soc. Trop. Med. Hyg., 91: 353-357.

Tanner M. (1989). Evaluation of public health impact of schistosomiasis. Trop. Med. Parasitol., 40: 143-148.

Vidigal T. H. A.; Spatz, L.; Nunes, N. D.; Simpson, A. J.; Carvalho O. S. and Dias N. E. (1998a). Biomphalaria spp.: identification of the intermediate snail hosts of Schistosoma mansoni by polymerase chain reaction amplification and 
restriction enzyme digestion of the ribosomal RNA gene intergenic spacer. Experimental Parasitol.89: 180-187.

Vidigal. T. H.A.; Dias, N. E.: Spatz L.; Nunes, N. D.: Pires R. E.; Simpson, A. J. and Carvalho, O. S.(1998b). Genetic variability and identification of the intermediate snail hosts of Schistosoma mansoni. Memórias do Instituto Oswaido Cruz.,93:103-110.

Vidigal, T. H.; Caldeira, R. L.; Simpson, A. J. G. and Carvalho, O. S. (2000). Further Studies on the Molecular Systematics of Biomphalaria Snails from Brazil. Memórias do Instituto Oswaldo Cruz.,95(I): 57-66.

Ueki K.; Parisi, J. E. and Onofrio, BM. (1995). Schistosoma mansoni infection involving the spinal cord. Case report. J. Neuro.,82: 1065-1067.

West, D.F.; Payette, T.; Mundy, T. and Black, I. V.(1997). Regional molecular genetic key of thirteen snow pool Aedes species (Diptera: Culicidae) in northern Colorado. J. Med. Entomol., 34: 404-410.

WHO (1993). The control of schistosomiasis: second report of the WHO expert committee. World Health Organization, Geneva, WHO Technical Report Series, 830.

WHO (1994). Bench aids for the diagnosis of intestinal parasites. World Health Organization, Geneva.

WHO (1999). Report of the WHO informal consultation on schistosomiasis control. World Health Organization, Geneva, WHO/ CDS/ CPC! SIP/ 99. 2.

Wu, Z.; Nagano, I.; Pozio, E. and Takahashi Y. (1999). Polymerase chain reaction-restriction fragment length polymophism (PCR-RFLP) for the identification of Trichinella isolates. Parasitol., 118: 211-218. 


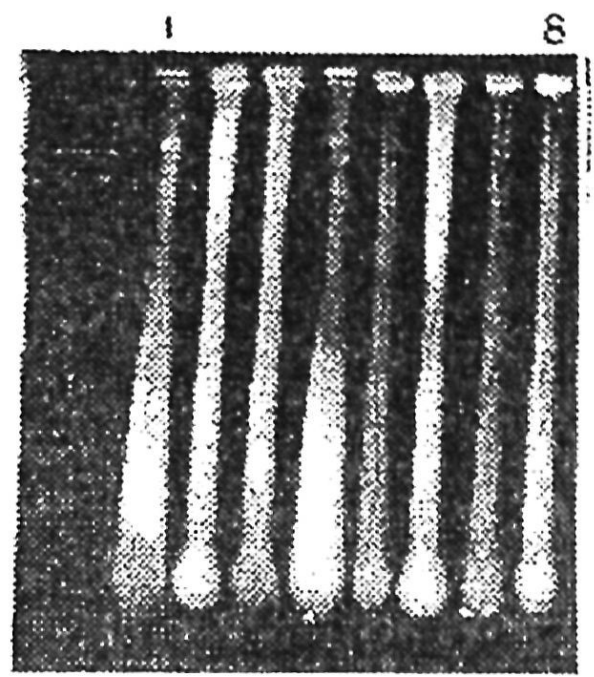

Figure 1. DNA genome from S. mansoni and S. hoemestobium isolales. lames 1 - 4 represent the $5 \mathrm{~N} \wedge$ genome of S. mansoni which was isolated Irom El-Qualyohia. I:I-Sharkaia. Fil-Dakahlia and Asuil provinces. respectively and lanes 6-9 represent the DNA genome of 5 . hesemestobium which was isolated all from the same proviness.

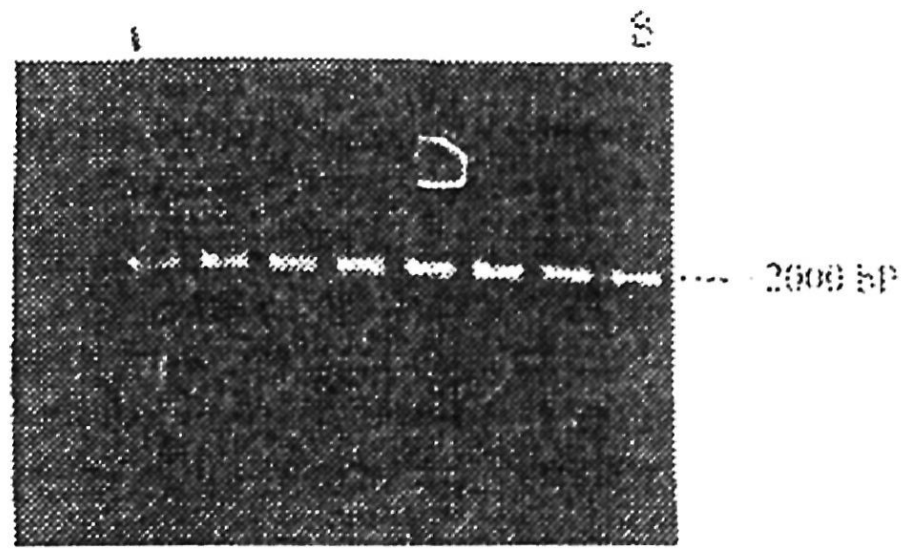

Figure 2. symbolized full-scgnent srDNA of Schistosomer sp. isolates. limes 14 represented srDNA of $S$. mansoni from l:1-Qualyobia. 1:1Sharkaia, El-Dakahlia and Asuit provinces. respectively. lanes 5 ... 8 represented $\operatorname{srDN} \wedge$ of $S$. hacmatobitem from the same provinces. 


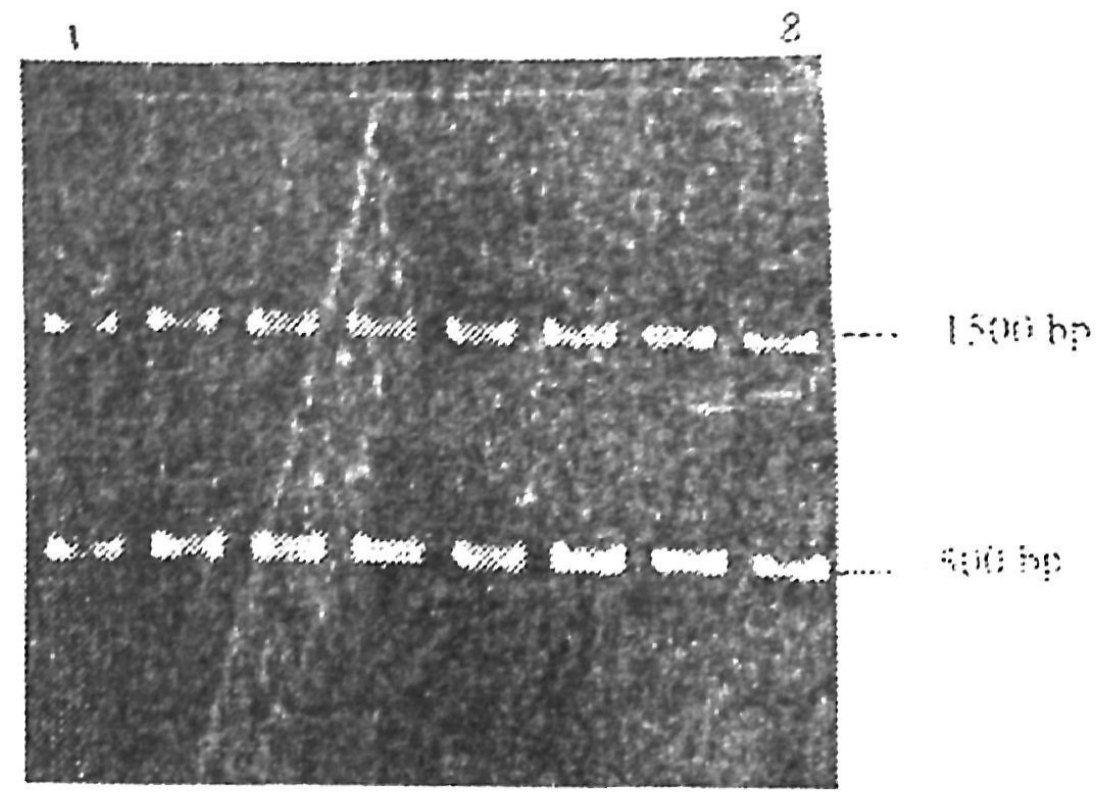

Figure 3. shows the representative RFLPS patterns from $S$. mansoni and $S$. haematobium from each isolate (province) with BspMI. which produced roughly the same fragments ( 2 bands, -500 and $-1500 \mathrm{bp}$, for all isolates). $\quad$ ।

8

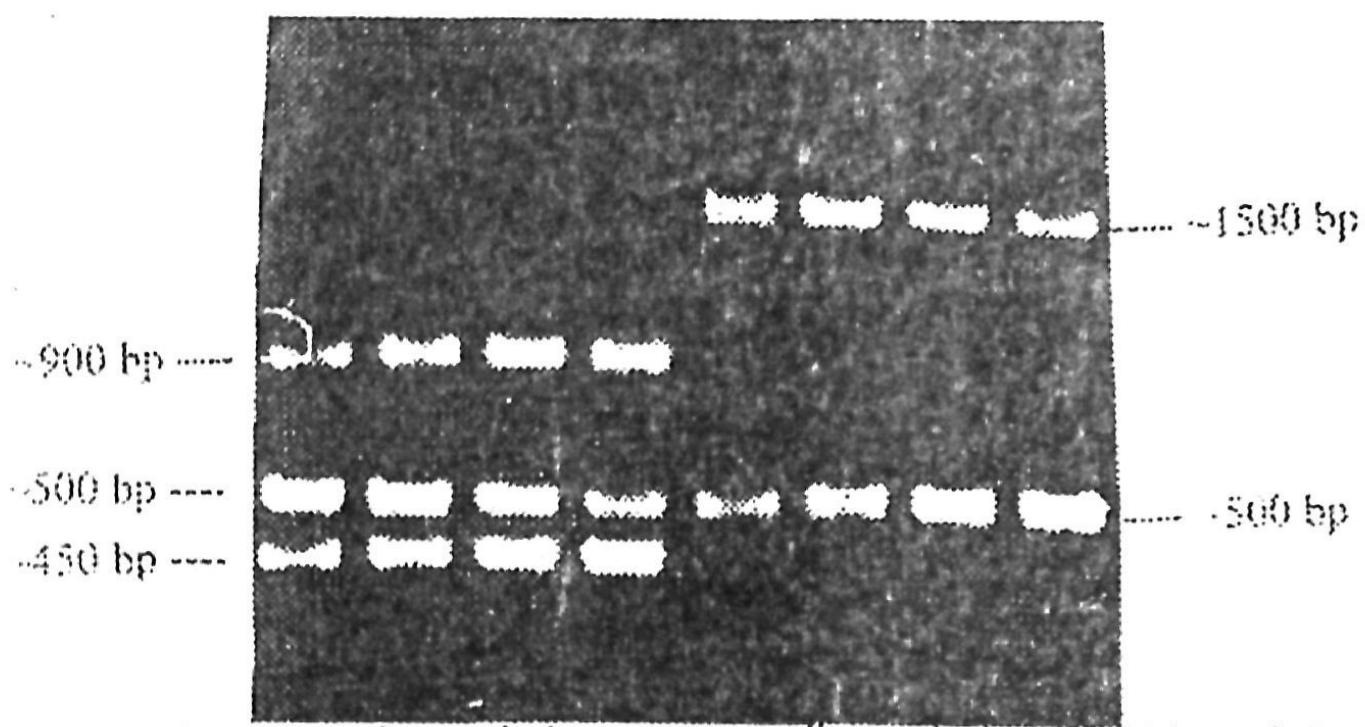

Figure 4. show's Accl restriction enzyme digested the nstbNA of $S$ memsoni into 3 different band sires $(-450, \ldots 500$. and -9$)$ s) bp. lanes $1-4)$ from all provinces's isolates. The same restricion encyme cut the nsrDNA of $S$. hacmutobium to 2 bands $(-500$ and -1500 bp. lanes $5-8)$ lrom all provinces's isolates. 




Figure 5. The analysis of the nuclear srRNA gene, Avall enzyme resulted in wo RFI.PS with S. mansoni ( -800 and $\sim 1200$ bp, lanes $1-4$ ). but digested nsrDNA of $S$. haemetobium into three patterns $(-500,-600$ and -900$)$.

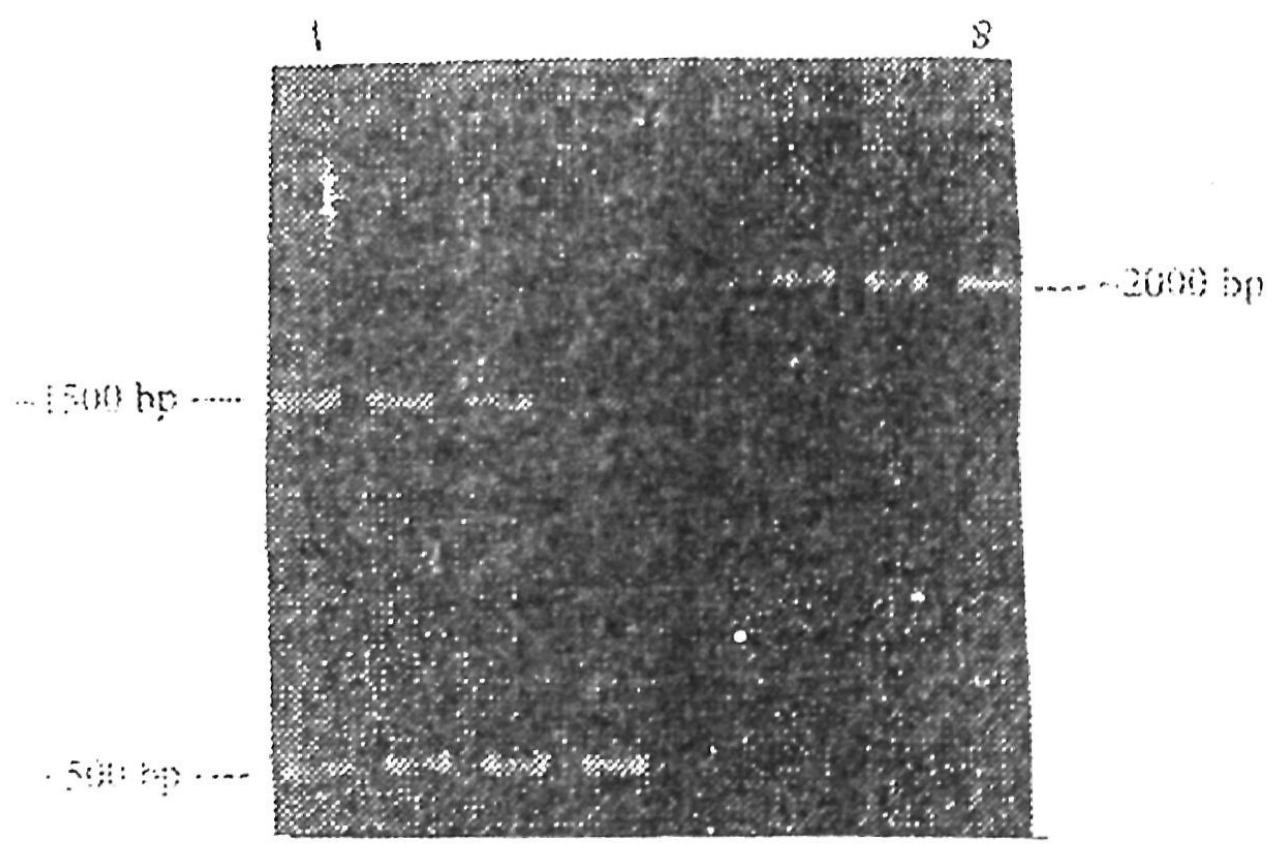

Figure 6. The nuclear gene of $S$. mansoni digested uniquely by SnaBI $(-500$ and -1500 bp. lanes ! - 4), whereas S. incemcrobium nuciear gene was not digested all all by this restriction entyme (lanes 5 - 8 ). 